Article

\title{
Sustainable Development of the Historic Centre of Naples: The Impact of Vehicular Traffic and Food Service Business on Air Quality
}

\author{
Fabio Murena \\ Chemical, Materials and Production Engineering Department, University of Naples "Federico II", \\ 80125 Naples, Italy; murena@unina.it
}

Received: 2 July 2020; Accepted: 29 July 2020; Published: 2 September 2020

\begin{abstract}
Monitoring campaigns were carried out to assess the impact of vehicular traffic and food service business on the air quality in the historic centre of Naples. These campaigns monitored fine particles (FPs) from 20 to $1000 \mathrm{~nm}$, using a condensation particle counter (CPC) in four connected streets, during a period of four weeks, from 7 November to 7 December 2019. Two streets were pedestrian only, while the others had average traffic. The following variables were considered while analysing the data-street geometry, and traffic and food service business emissions. The results showed prevalent air contamination, with some critical situations. The FP concentration values in the pedestrian streets were similar to the average values measured at the roadside of other European cities. However, the FP concentration values measured on the streets with average traffic, were twice that of their European counterparts. Spatial maps of FP concentration were produced to assess the impact of food service business emissions at the street level. The maps showed an insignificant contribution to FP pollution. However, it must be noted that emissions of the food service businesses were not measured at the roof top level in this study. The aspect ratio $(\mathrm{H} / \mathrm{W})$ played a relevant role on FP concentration, as an increase in aspect ratio correlated to an increase in FP concentration. These findings showed critical preliminary information for the sustainable development of the historic centre of Naples, which should be confirmed through a long-term monitoring campaign.
\end{abstract}

Keywords: air quality; historic centre; sustainable development; traffic; food service; fine particles; Naples

\section{Introduction}

In recent years, the historical centres of many Mediterranean cities are experiencing significant transformations. The rapid growth of tourism caused food service business and new forms of private hospitality (bed and breakfast, holiday homes, etc.) to open, which contributes to vehicular traffic. The atmospheric emissions of these activities can jeopardise air quality and human health.

Air quality inside the urban canopy layer (UCL), the layer from ground to building rooftops, represents one of the principal challenges for the sustainable development of cities [1], as air pollution in urban areas poses a major threat to health and climate. More than $80 \%$ of people living in urban areas are exposed to air quality levels that exceed the WHO guideline limits [2]. The WHO air quality guidelines for particulate matter (PM) $\mathrm{PM}_{2.5}$ and $\mathrm{PM}_{10}$, respectively, are-10 and $25 \mu \mathrm{g} / \mathrm{m}^{3}$ annual mean and $24 \mathrm{~h}$ mean, and 20 and $50 \mu \mathrm{g} / \mathrm{m}^{3}$ annual mean and $24 \mathrm{~h}$ mean (2005 update). Therefore, the WHO estimates that the combined effects of ambient (outdoor) and indoor air pollution kill about seven million people worldwide every year, as a result of increased mortality from stroke, heart disease, chronic obstructive pulmonary disease, lung cancer, and acute respiratory infections. 
Worldwide air quality management is generally driven by national legislation that sets quality standards in order to avoid health issues in the human population. In European countries, the reference regulation is established by the 1996/62/CE directive, followed by several other directives that define the limit values, common procedure to measure air quality, and quality criteria of the collected data. Main sources of single airborne pollutants vary among urban areas in the world. Traffic is generally the main source of nitrogen oxides (NOx) in urban areas [3]. Both $\mathrm{PM}_{10}$ and $\mathrm{PM}_{2.5}$ derive from vehicular traffic and fuel combustion for heating and food preparation, especially biomass [4]. In port cities, sulphur oxide (SOx) emissions might mainly be caused by ships [5]. The importance of in-atmosphere production of secondary pollutants like $\mathrm{PM}_{2.5}$ must also be considered [6], which receive a significant contribution from other anthropogenic activities like agriculture and animal husbandry. Information on indoor air pollution and air quality guidelines can be found in WHO guidelines for indoor air quality [7].

The correlation between air quality management and urban sustainability is an ever more important consideration for urban municipalities. Sustainable urban design can reduce anthropogenic emissions, improve urban ventilation, and increase green areas, thus, minimizing human exposure. Until recently, air pollution in urban areas was rarely observed through a holistic lens, based on a sustainable plan of development. It is also worth noting that air quality can be a decisive factor in the assessment of the attractiveness of a city as a tourist destination [8].

The sustainable development of urban areas implies [9] three main issues-(i) connection between environmental consideration and economic policy-making; (ii) social equity; and (iii) meeting the needs of the present generation without compromising the needs of future ones. Similarly, Do and Thomas [10] individuate three pillars of sustainable landscape development-society, economy, and environment (Culture-Heritage-Social-History, Commerce-Craft-Agriculture and Environment-Ecology-Habitation).

The importance of spatial structure in a city on urban sustainability was demonstrated by several studies. Urban forms are often classified as: (i) corridor city characterized by growth in linear corridors with origin in the city centre, supported by high-quality transport infrastructure (highways); (ii) compact city with high density and mixed-land uses so that complementary functions are located close by to one another (housing, shopping, offices, etc.), and (iii) disperse city characterized by low density, large area requirements, and separation into distinct zones for residential, commercial, or industrial uses.

It was claimed [11] that more compact, high-density, and mixed-use urban forms can be environmentally sound, efficient for transport, socially beneficial, and economically viable. One of the main innovative urban and transport planning studies for a sustainable development of urban areas is represented by the Barcelona Superblock model [12]. The Superblock project re-organises the structure of the city of Barcelona in 503 cells with standard dimensions of $400 \times 400 \mathrm{~m}^{2}$ transforming the city into connected neighbourhoods with a mixed-land use. The results showed the potentiality to reduce premature mortality burden through reductions in air pollution, noise and heat, and increased access to green space. Other authors report more specific effects of the structure of urban areas on air quality. Kang et al. [13] studied the effect of urban form on ozone concentration in Korea. They find that a city with a greater degree of mixed-land use and clustered and concentrated spatial patterns is more likely to experience fewer days of extreme ozone concentration. Jung et al. [14] investigated the relationship between urban structures and emissions of air pollutants. Finally, Borrego et al. [15] studied three imaginary cities with different urban structures-corridor city, disperse city, and compact city.

These studies did not give information on the influences of the city structure at a local scale, where specific sources like urban freeways or street canyons can represent a problem. In fact, streets are an essential element in shaping the urban environment, as they are places with different kinds of business, private and public activities, services, squares, meeting points, places of historical memory and rest areas. However, streets are also places where most problems of cities arise [16]. 
The negative effect of street canyons, particularly deep street canyons, on pollutant dispersion is well known. In fact, in new urban areas, their construction should be avoided [17], and the creation of urban open spaces would reduce pollutant exposure, as demonstrated in a 3D idealized urban-like geometries simulation study [1].

Street canyons are generally classified on the basis of the aspect ratio $\mathrm{H} / \mathrm{W}$, where $\mathrm{H}$ is the building height and $\mathrm{W}$ is the street width, as low-rise street canyon when $\mathrm{H} / \mathrm{W}<0.7$; regular street canyon when $\mathrm{H} / \mathrm{W}$ is in the range 0.7-1.5; and deep street canyon if $\mathrm{H} / \mathrm{W}>1.5$ [18]. In the function of the aspect ratio, different flow regimes occur in street canyons-isolated roughness flow, wake interference flow, and skimming flow [19]. In the case of the skimming flow regime, the bulk of the above-roof flow does not penetrate the canyon and a single vortex forms when $0.7<\mathrm{H} / \mathrm{W}<1.5$ while if $\mathrm{H} / \mathrm{W}>1.5$, the street canyon is classified as deep. In this case, two or more counter-rotating vortices might form [20], with the bottom vortex weaker than the upper one.

To better characterize street canyons, a second aspect ratio is defined as $\mathrm{L} / \mathrm{H}$, where $\mathrm{L}$ is the length of the street between two consecutives crossroads. Real street canyons are then lumped into three categories-short $\mathrm{L} / \mathrm{H}<3$; medium $3<\mathrm{L} / \mathrm{H}<5$; and long canyons $\mathrm{L} / \mathrm{H}>5$.

The different flow regimes influence the mass transfer rate between the street canyon and the surrounding volumes, particularly the upper atmosphere [21]. The accumulation of pollutants in a street canyon depends on the mass transfer rate. In the case of deep street canyons, mass transfer rate is at a minimum [22] and pollutants emitted by local sources tend to accumulate.

In absence of a holistic approach, the management of air pollution in an urban area can be unsuccessful. Traffic management strategies-even including changes in transport infrastructure, traffic regulation, speed limit or fleet composition-might have limited impact on air quality [23]. Green roofs have the potential of delivering environmental benefits in urban areas, but there is a high need for a multi-disciplinary collaboration to deliver a cost-effective green roof design based on local requirements [24]. Moreover, in the case of old or historical centres, this solution is difficult to apply, as it is more appropriate for new buildings and new cities. In case of large megacities with a high level of air pollution, modern architecture projects with a futuristic design are proposed [25]. Among these new solutions, solar towers show promising outlooks [26]. Finally, it must be remembered that the issue of sustainable development concerns not only big or megacities but also villages, cities, and small towns [10].

Sustainable development also promotes social equity-every citizen has the right to same air quality. As per WHO guidelines [2], characteristics of air quality should be: 10 and $25 \mu \mathrm{g} / \mathrm{m}^{3}$ annual and $24 \mathrm{~h}$ mean for $\mathrm{PM}_{2.5}$, and 20 and $50 \mu \mathrm{g} / \mathrm{m}^{3}$ annual and $24 \mathrm{~h}$ mean for $\mathrm{PM}_{10}$, respectively; $40 \mu \mathrm{g} / \mathrm{m}^{3}$ annual mean and $200 \mu \mathrm{g} / \mathrm{m}^{3}$ as $1 \mathrm{~h}$ mean for $\mathrm{NO}_{2}, 100 \mu \mathrm{g} / \mathrm{m}^{3}$ as $8 \mathrm{~h}$ mean for $\mathrm{O}_{3} ; 20 \mu \mathrm{g} / \mathrm{m}^{3}$ as $24 \mathrm{~h}$ mean and $500 \mu \mathrm{g} / \mathrm{m}^{3}$ as $10 \mathrm{~min}$ mean for $\mathrm{SO}_{2}$. These values are still rarely guaranteed. In the city of Houston (Texas), a study of air pollution on health impacts linked to premature deaths at the census-tract level, showed that premature deaths attributable to air pollution were higher in areas with lower income households [27]. Higher $\mathrm{NO}_{2}$ levels were observed in socioeconomically deprived areas of European Metropolises, as demonstrated by an ecological study within the European project EURO-HEALTHY [28].

The historical centre of Naples extends for about $17,000 \mathrm{~km}^{2}$ and is the largest in Europe (about $14.5 \%$ of the whole urban area). In 1995, it was listed among the UNESCO world heritage sites. Apart from the historical centre, a large part of Naples is of old design. Both historical and old areas of Naples represent live heritage spaces unique for their abundance of historical sites, social organisation, and cultural traditions. Naples does not have a single centre like most cities, and is instead characterized by a circular development, starting from the historical centre. Instead, due to the orography and the presence of the seacoast, many different centres or districts could be individuated in Naples. All districts have important common characteristics-high-density of population, narrow streets, mixing of different social classes and land use, presence of several craft activities and an abundance of historical sites. All these districts are well-connected both to one another and to other 
city districts. In some cases, they are also crossed by the main traffic arteries. In Naples, there are no urban freeways but simply roads larger than the others. Typically, they are about $15 \mathrm{~m}$ wide. All the other streets are very narrow, with a typical value of aspect ratio $(\mathrm{H} / \mathrm{W})>3$. Therefore, there are deep street canyons that are characterized by an ineffective mass transfer with the surrounding atmosphere. Consequently, high pollutant concentrations are measured [29,30].

From 1998 to 2017, the presence of tourists in Naples has doubled from 1.6 to 3.2 million per year. The increased presence of tourists determined the opening of numerous commercial activities (food service businesses and hospitality) and the increment of vehicular traffic, amplifying health hazards linked to air pollution.

This study deals with sustainable development of the historical centre of Naples, focusing on a single but crucial aspect connected with the environment and human health-air quality.

\section{Experiments}

A P-Track 8525 ultrafine particle counter (CPC) was used to measure particle number concentration from 20 to $1000 \mathrm{~nm}$. This range of measure corresponded with the fraction of atmospheric aerosol named fine particles (FPs), and it also included ultrafine particles (UFPs $<100 \mathrm{~nm}$ ) [31]. Full scale of the instrument was $5.010^{5} \# / \mathrm{cm}^{3}$. The instrument was calibrated through simultaneous measures [32] with a $\mathrm{PM}_{2.5}$ analyser (OPSIS SM200).

The area monitored was in the historical centre of Naples (Figure 1). Four streets were monitored. These streets were: "Via Chiaia", a pedestrian street with few food establishments; "Via Gradoni", an uphill street with vehicular traffic; "Via Nardones", an uphill street with vehicular traffic; and "Via Toledo", a pedestrian street with some food establishments and some intersections with busy roads. Their main geometric parameters are reported in Table 1. Each road was subdivided into tracts with quite constant values of building height and street width. All tracts were medium or long deep street canyons, with an average aspect ratio (H/W) varying from 1.93 to 4.04 . Only one tract was classified as short street canyon.

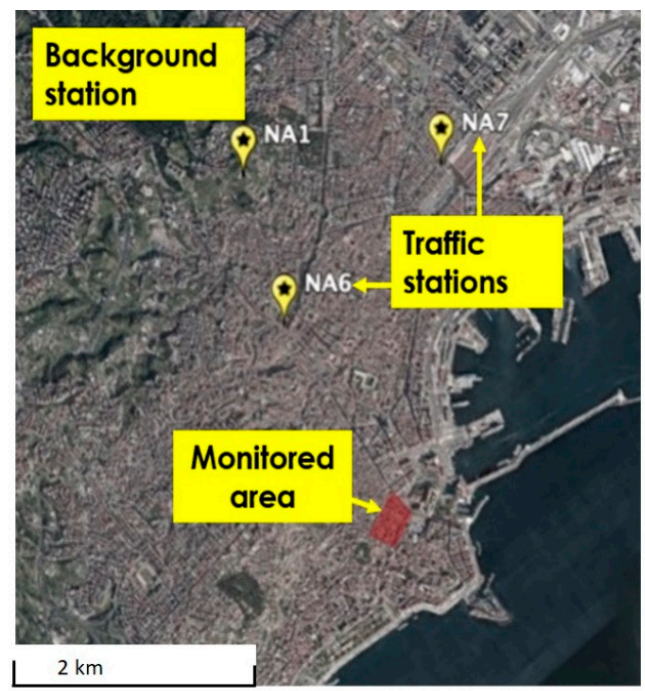

(a)

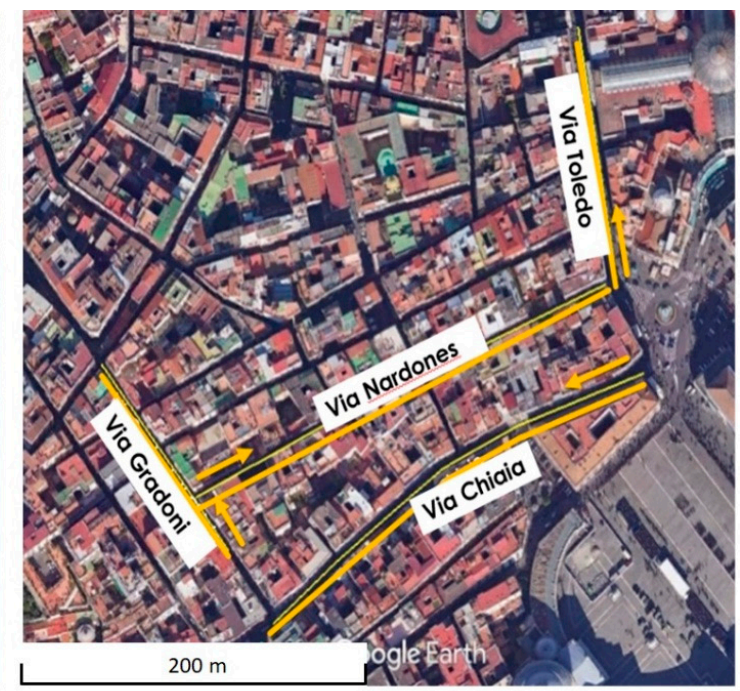

(b)

Figure 1. Map of Naples showing the location of the monitored area and of the fixed stations belonging to the air quality network (a). Zoomed-in view of the monitored area with the four streets (b).

The monitoring campaign lasted for 4 days - 7, 20, 25 November and 7 December 2019. Average hourly values are measured at 9-10, 12-13, and 18-19. Each street was walked two times in an hour, always repeating the same path (same direction indicated by arrows in Figure 1, same side of the street and same distance from the street edge) and at the same speed by the same operator. In this way, a good reproducibility of measures was guaranteed. Each measurement lasted about 5 min per 
street. Before starting a new measurement along another street, the time average value of FPs was downloaded and stored. Therefore, in an hour, 8 measurements, two for each street, of about 5 min each, were obtained. The two $5 \mathrm{~min}$ averages obtained in the same hour along the same street were used to evaluate a $10 \mathrm{~min}$ average that was assumed to be the hourly average for that street in that hour.

During measurements, it is especially important to maintain the CPC in a horizontal position, because it cannot take measurements when tilted and an error message is produced. For this reason, the CPC was put in a shoulder bag and held horizontal by the operator. The efficiency of the set-up realized was demonstrated by the absence of the tilting error messages received during measurements. A Teflon tube was used to guarantee the constancy of the sampling height. One side of the sampling tube was connected to the inlet of the CPC and the other side was fixed at the right shoulder of the operator, at a height of about $1.5 \mathrm{~m}$.

Table 1. Main geometric parameters of the four monitored streets.

\begin{tabular}{|c|c|c|c|c|c|c|c|}
\hline Street & Tract & $L(m)$ & $\mathbf{H}$ & $\begin{array}{c}W \\
(\mathrm{~m})\end{array}$ & H/W & $\mathrm{L} / \mathrm{W}$ & Classification \\
\hline \multirow{4}{*}{ Via Chiaia(pedestrian) } & 1 & 114 & 20.00 & 11.63 & 1.72 & 9.80 & Long deep \\
\hline & 2 & 40 & 20.00 & 9.70 & 2.06 & 4.12 & Medium deep \\
\hline & 3 & 161 & 22.99 & 9.70 & 2.37 & 16.60 & Long deep \\
\hline & Total & 315 & 20.00 & 10.34 & 1.93 & & Deep \\
\hline \multirow{5}{*}{ Via Gradoni(traffic) } & 1 & 74 & 27.00 & 6.11 & 4.42 & 12.11 & Long deep \\
\hline & 2 & 38 & 20.69 & 5.90 & 3.51 & 6.44 & Medium deep \\
\hline & 3 & 27 & 22.00 & 6.16 & 3.57 & 4.38 & Medium deep \\
\hline & 4 & 39 & 18.74 & 6.16 & 3.04 & 6.33 & Medium deep \\
\hline & Total & 178 & 20.37 & 6.08 & 3.35 & & Deep \\
\hline \multirow{4}{*}{ Via Nardones(traffic) } & 1 & 113 & 21.35 & 5.80 & 3.68 & 19.48 & Long deep \\
\hline & 2 & 59 & 24.81 & 5.80 & 4.28 & 10.17 & Long deep \\
\hline & 3 & 143 & 22.04 & 5.80 & 3.80 & 24.66 & Long dee \\
\hline & Total & 315 & 23.43 & 5.80 & 4.04 & & Deep \\
\hline \multirow{4}{*}{ Via Toledo(pedestrian) } & 1 & 74 & 26.84 & 12.70 & 2.11 & 5.83 & Medium deep \\
\hline & 2 & 34 & 26.19 & 12.70 & 2.06 & 2.68 & Short deep \\
\hline & 3 & 43 & 25.71 & 12.70 & 2.02 & 3.39 & Medium deep \\
\hline & Total & 151 & 25.95 & 12.70 & 2.04 & & Deep \\
\hline
\end{tabular}

\section{Results}

Before analysing the experimental data, information on aerosol air pollution in Naples during the monitoring campaign was collected. Data from three fixed stations were considered-NA1 (urban-background), NA6 (urban-traffic), and NA7 (urban-traffic) (Figure 1). These were the nearest to the area (2-3 km of distance from the monitored area). In Naples, the limit value (LV) for PM 10 daily average — established as a maximum of 35 days a year — of over $50 \mu \mathrm{g} / \mathrm{m}^{3}$ was often exceeded and $\mathrm{PM}_{2.5}$ year average was generally very close to the limit value of $25 \mu \mathrm{g} / \mathrm{m}^{3}$. During the monitoring campaign, average values of both $\mathrm{PM}_{10}$ and $\mathrm{PM}_{2.5}$ were well below the limit values established by EC (Figure 2), at all three fixed stations. This finding is of interest in the discussion of data collected during the monitoring campaign.

In Figure 3, average FPs concentration measured in each of the four streets (Table 1) is reported. The dramatic difference between the pedestrian streets (Via Chiaia and Via Toledo) and the trafficked streets (Via Gradoni and Via Nardones) is evident. In pedestrian streets, the average concentration was in the range $3.08-3.5910^{4} \# / \mathrm{cm}^{3}$, while in the trafficked streets, the range was $7.92-8.1110^{4} \# / \mathrm{cm}^{3}$. It is important to remember that the four streets were connected and were close to each other. This was a confirmation of the large spatial variability observed inside many urban areas [33], and in Naples, as well [34]. Moreover, as reported before, the aerosol concentration measured by fixed stations in the same hours of the monitoring campaign was quite low (Figure 2). Therefore, concentrations reported in Figure 3 are mainly due to local sources. The absolute FPs concentrations could be compared with those reported by Kumar et al. [33] in a survey of UFPs concentration at roadsides, in 42 cities around the world. In European cities, the average value was $3.15 \pm 1.6010^{4} \# / \mathrm{cm}^{3}$. Therefore, values 
monitored in pedestrian streets (Figure 3) were similar to the average value at roadsides, in European cities, but those measured in the two trafficked streets were more than two times the average value. As a matter of fact, FPs showed a high spatial variability inside urban areas and the concentration varied from factors of 2 in small cities [35] to about $10[36,37]$ in large cities. The spatial differences were strongly affected by the characteristics of the receptor sites (background, open roads, squares, traffic streets).

The difference between pedestrian and trafficked streets, observed in Figure 3, could be attributed to emission of vehicles passing during the monitoring activity. Murena and Prati [38] report that the time pattern of FPs in a deep street canyon was strictly correlated with the traffic flow, especially of high emitter vehicles.

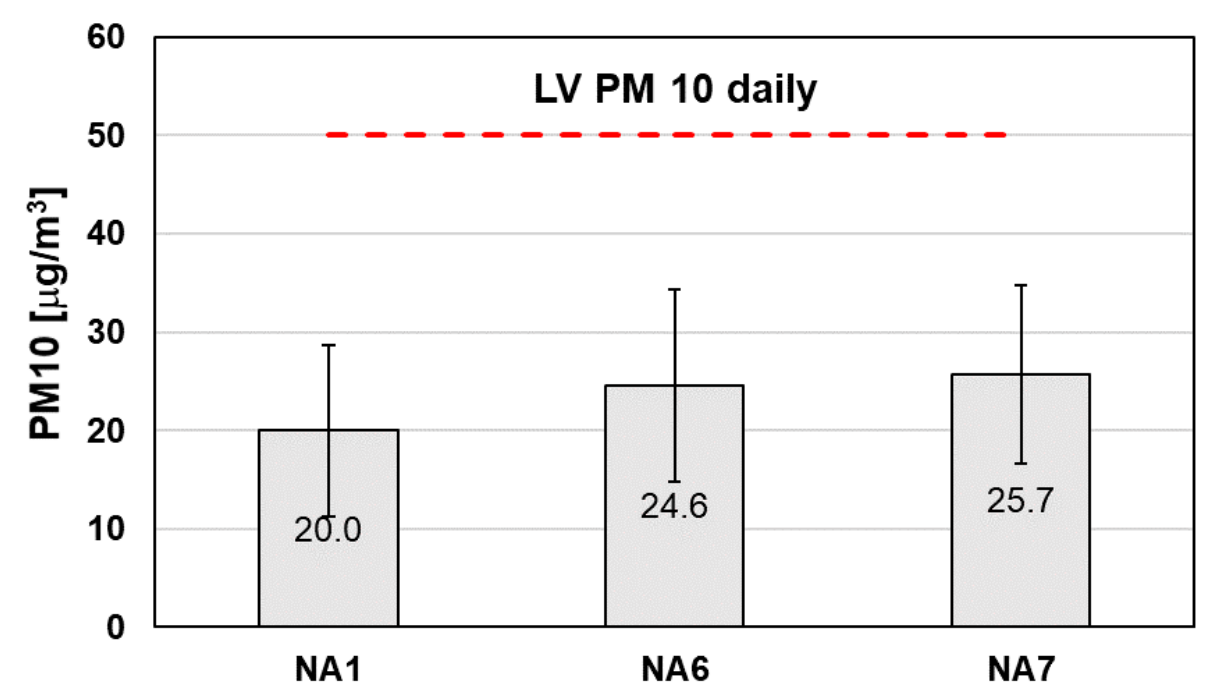

(a)

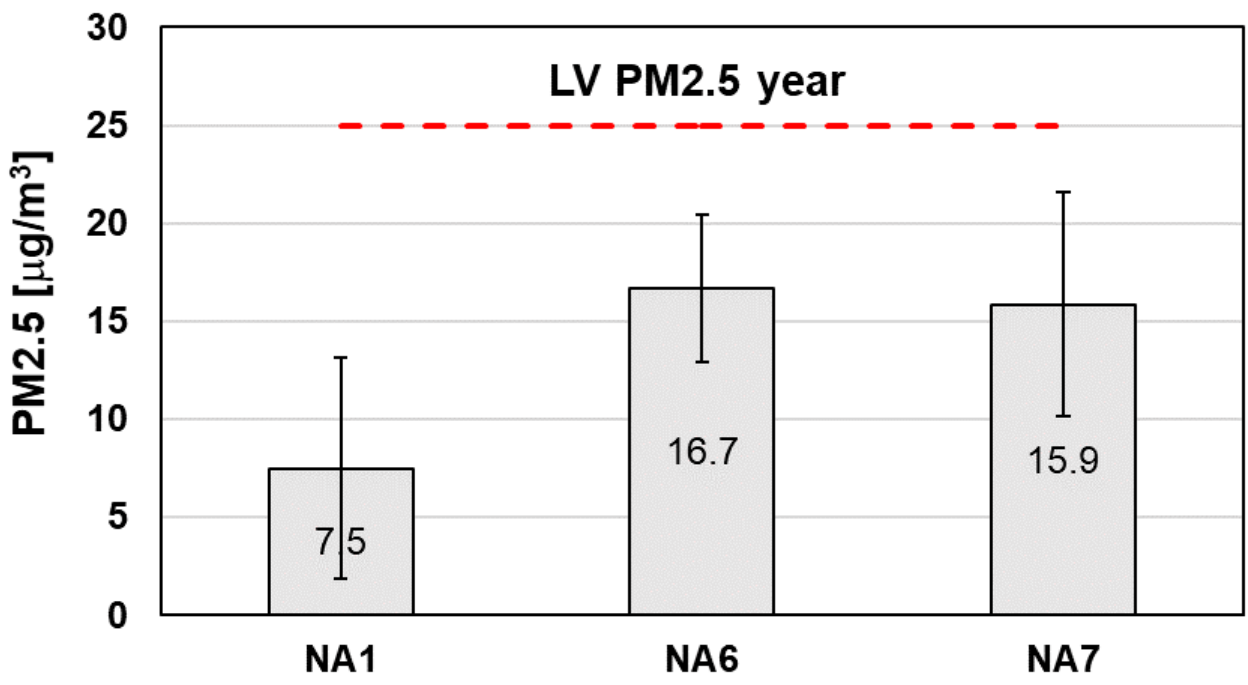

(b)

Figure 2. Average $\mathrm{PM}_{10}$ (a) and $\mathrm{PM}_{2.5}$ (b) concentration measured at fixed stations during the monitoring campaign. Red lines represent limit values (LV) in European countries.

Studies on FPs in the urban area of Naples are few. A study on particular matter characteristics $\left(\mathrm{PM}_{10}\right.$ and $\left.\mathrm{PM}_{2.5}\right)$ [39] showed the existence of two contributions to $\mathrm{PM}-$ one from local sources and another from long-range transport.

To better understand the contribution of food service businesses located along Via Chiaia and Via Toledo, a map of the two streets is reported with a diagram of the average FPs concentration 
(Figure 4). The yellow points indicate the presence of food establishments, while the red ones indicate the presence of a crossroad with a trafficked street. It was evident that the peak of FPs concentration generally corresponded to crossroads, while concentration peaks were not observed corresponding to food establishments.

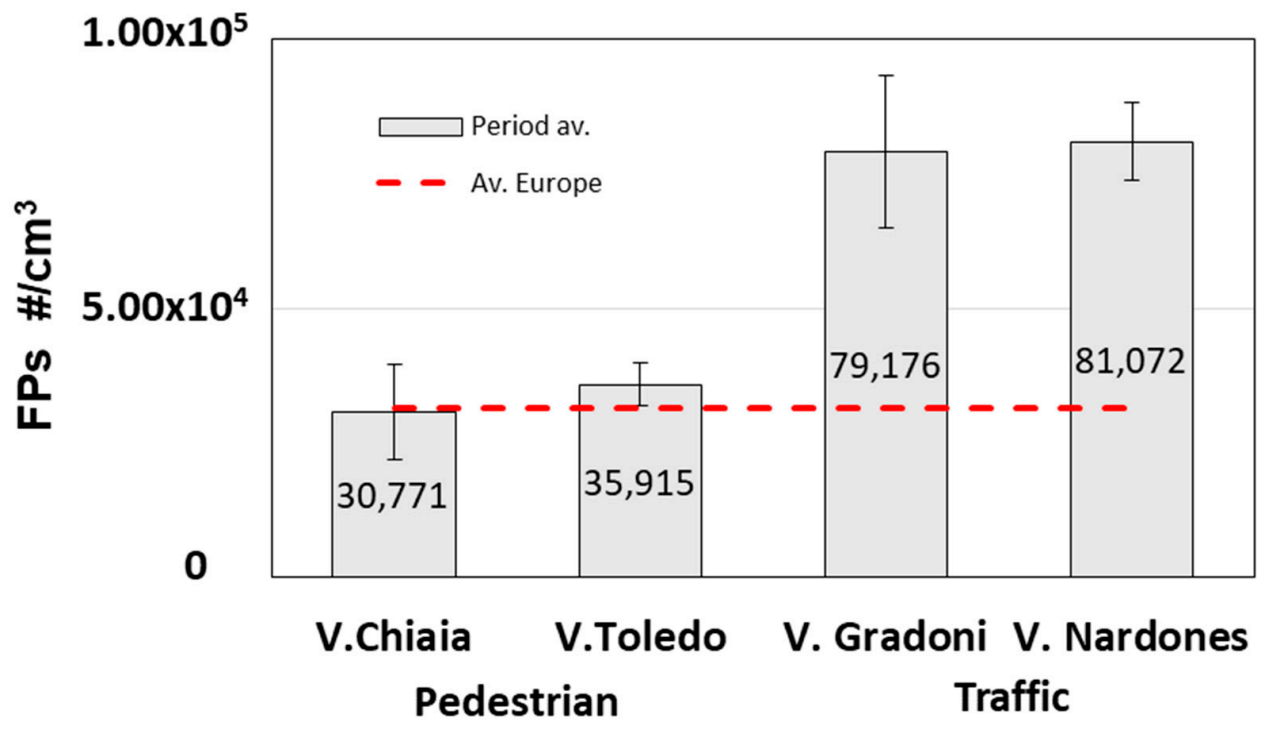

Figure 3. Period average concentration of fine particles (FPs) during the monitoring campaign for each of the four streets. Red dotted line is the average concentration in Europe [33].

FPs concentration was already measured in previous monitoring campaigns in Naples [34], evidencing a large spatial variability inside the urban area. Values ranged from $3.2910^{3} \# / \mathrm{cm}^{3}$ at a background urban receptor site in a green area to $1.5710^{5} \mathrm{\#} / \mathrm{cm}^{3}$ in the proximity of a tunnel of vehicular traffic. A significant effect of the aspect ratio H/W on FPs concentration was observed. To verify this effect, data of FPs concentration measured in Naples in this and in a previous monitoring campaign [34] are reported in Figure 5, as compared to the aspect ratio H/W. Data reported in a study on the spatial variability of fine particle number concentration in the urban area of Naples [34], added to Figure 5, were collected from 4 April to 25 May 2018, using the same CPC adopted in the present study. A total of about one hundred $10 \mathrm{~min}$ average values of FPs concentration were measured. All receptor points were inside the urban area of Naples and include: (i) open roads, i.e., roads with buildings only on one side for which it was assumed that $\mathrm{H} / \mathrm{W}=0$ (Via Marina, Via C. Colombo); (ii) squares, in this case $\mathrm{H} / \mathrm{W}$ was evaluated by assuming $\mathrm{W}$ to be the average of the sides of the rectangular squares (Piazza Garibaldi, Piazza Municipio, Piazza Italia); and (iii) street canyons. For street canyons, H/W ranged between 0.62 (Viale Augusto) to 5.5 (Via Nardones). Data of the present monitoring campaign are reported in Figure 5, as green circles. Via Nardones is reported twice in Figure 5 (red circle for previous monitoring campaign [34] and green circle present study). Aspect ratio of Via Nardones are different because the receptor points were not the same in the two monitoring campaigns.

The correlation was good. By increasing the aspect ratio, the particle number concentration increased and the coefficient of determination was $\mathrm{R}^{2}=0.87$. In deep street canyons $(\mathrm{H} / \mathrm{W}>2), \mathrm{FPs}$ were always $>3.010^{4} \# / \mathrm{cm}^{3}$, even in pedestrian streets. At an aspect ratio greater than $\mathrm{H} / \mathrm{W}>3$ and in trafficked streets, FPs reached values $>6.010^{4} \mathrm{\#} / \mathrm{cm}^{3}$. Some other factors could influence the results reported in Figure 5, but they played a minor role. As an example, FPs measured at Via Marina, Via C. Colombo, and Piazza Municipio, could be influenced by ship emissions, as they were close to the port of Naples. The vehicular fleet transiting on all monitored streets was quite similar and so was the impact of domestic emissions. Therefore, Figure 5 indicates an important effect of $\mathrm{H} / \mathrm{W}$ on FPs concentration. 


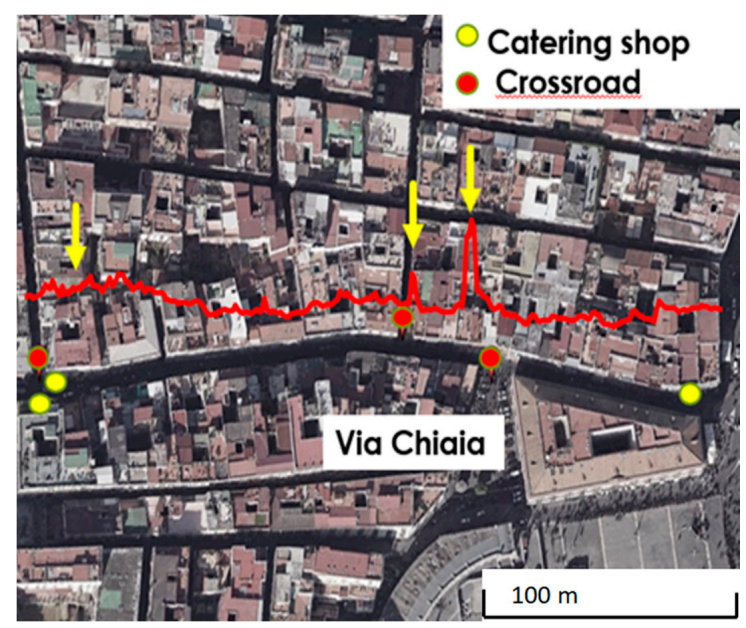

(a)

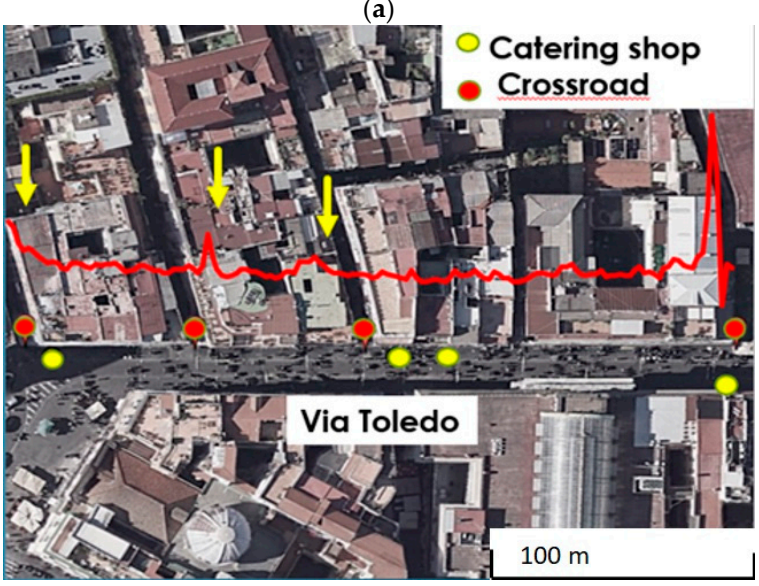

(b)

Figure 4. Spatial distribution of FPs concentration in pedestrian streets-(a) via Chiaia and (b) via Toledo. Yellow circles indicate the presence of a food establishment while red ones correspond to junctions with trafficked streets.

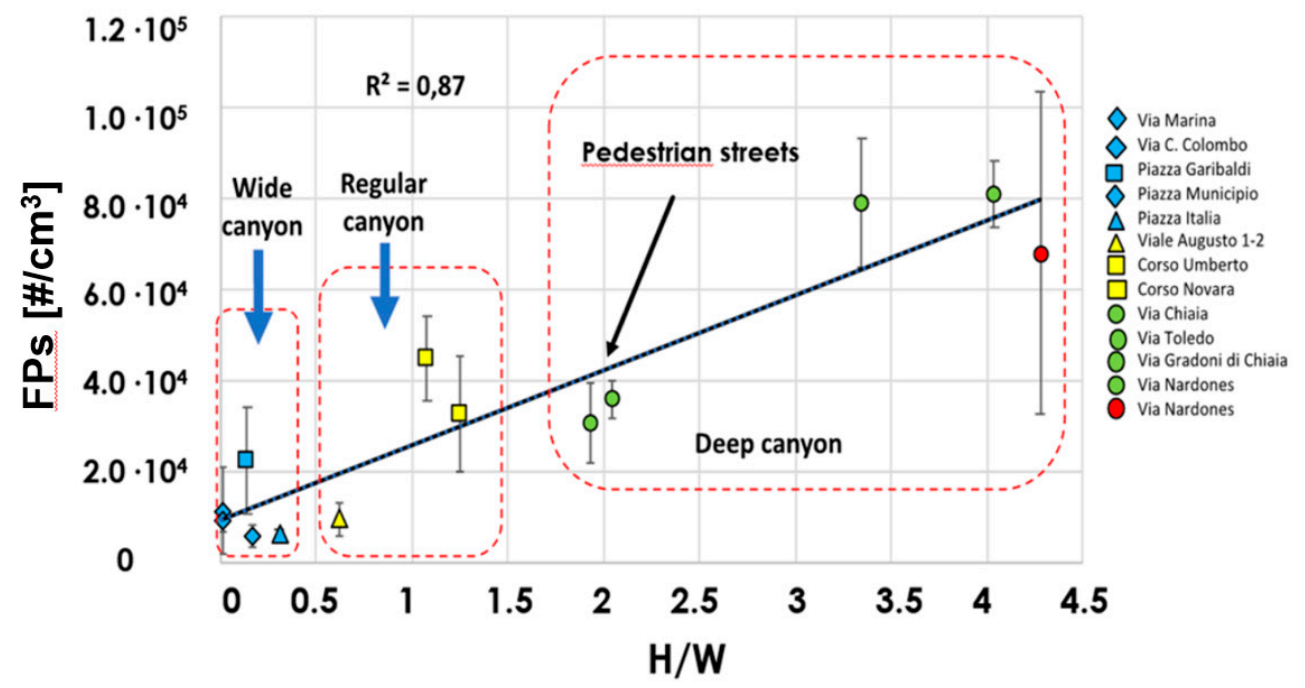

Figure 5. The effect of aspect ratio H/W on FPs concentration in Naples (green circles data are from this study, others are from [34]). 


\section{Discussion}

The results reported in Figure 3 indicate that in the historical centre of Naples, traffic emissions play a relevant role together with aspect ratio $(\mathrm{H} / \mathrm{W})$, while emissions from food businesses seem to be less relevant. However, a definitive answer to this last point could be given only after chimney emissions of these activities are also monitored at rooftops. The relevance of the impact of traffic emissions on air quality in Naples was already reported by Murena and Prati [38]. In particular, high emitter vehicles ( $5 \%$ of vehicles circulating) contribute to about $35 \%$ of FPs concentrations, in a deep street canyon located very close to the monitored area. High FPs concentration depends not only on the old vehicular fleet circulating in Naples with several high emitter vehicles but also on the high aspect ratio $(\mathrm{H} / \mathrm{W})$, generally $>3$. In Naples, most streets are very narrow $(5-7 \mathrm{~m})$ and buildings are not low $(>20 \mathrm{~m})$. This reduces the mass transfer between the canyon and the above atmosphere and the "breathability" of the street [40]. Therefore, pollutants accumulate at a pedestrian level. This finding has important health consequences. In fact, in these streets, the population density is very high, and many families live in typical small flats at street level—called "bassi"—where the concentration of pollutants is higher $[29,30]$. The negative effect of inhalable particles on human health is well known. A reduction of $\mathrm{PM}_{2.5}$ concentration has beneficial effects in terms of premature deaths. Sohrabi et al. [27] report that in Houston premature deaths due to $\mathrm{PM}_{2.5}$ correspond to $7.3 \%$ of all-cause premature deaths, while complying with the WHO air quality guideline values for $\mathrm{PM}_{2.5}\left(10 \mu \mathrm{g} / \mathrm{m}^{3}\right)$ prevent $0.9 \%$ of premature deaths.

As a result of restrictions established during lockdown to counter the spread of COVID-19 pandemic, air quality in Naples improved dramatically. $\mathrm{NO}_{2}$ concentration reduced by about $40 \%$ and $\mathrm{PM}_{10}$ by about $20 \%$ [41]. The main reason was due to reduction in traffic. The main goal for a sustainable development of the historical centre of Naples is the reduction of vehicular traffic, with a traffic ban of high emitter vehicles and incentives for the renewal of gasoline and diesel vehicles, with zero emission vehicles.

Transition towards sustainable development of the historical centre of Naples is not an easy task and at least a two-step approach [4] is necessary-a short-term phase aimed to a more environment friendly transport system and touristic activities, and a long-term approach to organize urban development in a sustainable way, by adopting an integrated urban planning. The urban structure of Naples is not regular, but some districts appear as blocks of variable dimensions. Therefore, an approach like that of the Superblocks in Barcelona [12] could be hypothesised.

The results reported were collected in the cold season (from 7 November to 7 December 2019). However, similar results would also be expected in other seasons. In fact, due to the temperate weather, the composition of vehicular circulating fleet (\% of two- and four-wheels vehicles) was quite constant during the year. The same was true for the traffic level. Additionally, touristic presence was quite constant during the year before the COVID-19 pandemic. The main differences between cold and warm season were domestic heating and cruise ship transit. However, both contributions to air pollution were not truly relevant in Naples [42].

\section{Conclusions}

The results reported showed how FPs concentration in the historical centre of Naples was quite high, and this finding confirmed results obtained in previous research activities in the same area, while monitoring campaigns of other pollutants.

The main results of this study were:

(i) Particle concentrations in the range 20-1000 $\mathrm{nm}$ measured with a condensation particle counter in deep traffic street canyons were on average about $8.010^{4} \mathrm{\#} / \mathrm{cm}^{3}$. This level could not be compared with limit values or guidelines but it was higher than the average value measured at roadsides in 42 cities in Europe $\left(3.15 \pm 1.6010^{4} \# / \mathrm{cm}^{3}\right)$, and represent a health issue for the area. These results 
were even worse as they were measured during days of low $\mathrm{PM}_{10}$ and $\mathrm{PM}_{2.5}$ concentration in the urban area.

(ii) A dramatic difference was observed between traffic $\left(8.010^{4} \# / \mathrm{cm}^{3}\right)$ and pedestrian streets (average $3.310^{4} \# / \mathrm{cm}^{3}$ ). The streets were remarkably close to each other, with similar $\mathrm{H} / \mathrm{W}$, the same orientation and other sources would contribute in the same way to FPs concentration. Therefore, it must be concluded that vehicular traffic was the main source of FPs in the area monitored.

As observed during lockdown, significant reductions of atmospheric pollutant emissions gave amelioration of air quality, in a short time (few days) and all residents experienced it. This evidence would incentivise public authorities in applying strong directives to reduce both vehicular and other atmospheric emissions.

Finally, it is necessary to highlight that the experimental dataset was limited in terms of the number of measurements collected. Therefore, reported findings need a confirmation through a long-term monitoring campaign, supported by the addition of a more sophisticated particle counter that is able to evaluate concentration of a wider range of sizes. This should be the object of future monitoring campaigns.

Funding: This research received no external funding.

Conflicts of Interest: The author declares no conflict of interest.

\section{References}

1. Sha, C.; Wang, X.; Lin, Y.; Fan, Y.; Chena, X.; Hang, J. The impact of urban open space and 'lift-up' building design on building intake fraction and daily pollutant exposure in idealized urban models. Sci. Total Environ. 2018, 633, 1314-1328. [CrossRef]

2. World Health Organization. Who Global Urban Ambient Air Pollution Database; World Health Organization: Geneva, Switzerland, 2016.

3. Degraeuwe, B.; Thunis, P.; Clappier, A.; Weiss, M.; Lefebvre, W.; Janssen, S.; Vranck, S. Impact of passenger car $\mathrm{NO}_{X}$ emissions on urban $\mathrm{NO}_{2}$ pollution-Scenario analysis for 8 European cities. Atmos. Environ. 2017, 171, 330-337. [CrossRef]

4. Aschmann, M. Addressing Air Pollution and Beyond in Ulaanbaatar: The Role of Sustainable Mobility. Geogr. Environ. Sustain. 2019, 12, 213-223. [CrossRef]

5. Merico, E.; Gambaro, A.; Argiriou, A.A.; Alebic-Juretic, A.; Barbaro, E.; Cesari, D.; Chasapidis, L.; Dimopoulos, S.; Dinoi, A.; Donateo, A.; et al. Atmospheric impact of ship traffic in four Adriatic-Ionian port-cities: Comparison and harmonization of different approaches. Transp. Res. Part D Transp. Environ. 2017, 50, 431-445. [CrossRef]

6. Masiol, M.; Squizzato, S.; Formenton, G.; Md Badiuzzaman, K.; Hopke, P.K.; Nenes, A.; Pandis, S.N.; Tositti, L.; Benetello, F.; Visin, F.; et al. Hybrid multiple-site mass closure and source apportionment of $\mathrm{PM}_{2.5}$ and aerosol acidity at major cities in the Po Valley. Sci. Total Environ. 2020, 704, 135287. [CrossRef] [PubMed]

7. World Health Organization. WHO Guidelines for Indoor Air Quality: Selected Pollutants; The WHO European Centre for Environment and Health, Bonn Office: Bonn, Germany, 2010; ISBN 9789289002134.

8. Łapko, A.; Panasiuk, A.; Strulak-Wójcikiewicz, R.; Landowski, M. The State of Air Pollution as a Factor Determining the Assessment of a City's Tourist Attractiveness-Based on the Opinions of Polish Respondents. Sustainability 2020, 12, 1466. [CrossRef]

9. Mersal, A. Sustainable urban future: Environmental planning for sustainable urban development. Procedia Environ. Sci. 2016, 34, 49-61. [CrossRef]

10. Do, X.S.; Thomas, D.E.C. Urbanization and urban design in sustainable development, case study of the ToLich river regions in Hanoi. J. Urban Plan. Landsc. Environ. Des. 2017, 2, 37-52.

11. Dempsey, N.; Bramley, G.; Power, S.; Brown, C. The social dimension of sustainable development: Defining urban social sustainability. Sustain. Dev. 2011, 19, 289-300. [CrossRef]

12. Mueller, N.; Rojas-Rueda, D.; Khreis, H.; Cirach, M.; Andrés, D.; Ballester, J.; Bartoll, X.; Daher, C.; Deluca, A.; Echave, C.; et al. Changing the urban design of cities for health: The superblock model. Environ. Int. 2020, 134, 105132. [CrossRef] 
13. Kang, J.E.; Yoon, D.K.; Bae, H. Evaluating the effect of compact urban form on air quality in Korea. Environ. Plan. B Urban Anal. City Sci. 2019, 46, 179-200. [CrossRef]

14. Jung, M.C.; Park, J.; Kim, S. Spatial Relationships between Urban Structures and Air Pollution in Korea. Sustainability 2019, 11, 476. [CrossRef]

15. Borrego, C.; Martins, H.; Tchepel, O.; Salmim, L.; Monteiro, A.; Miranda, A.I. How urban structure can affect city sustainability from an air quality perspective. Environ. Model. Softw. 2006, 21, 461-467. [CrossRef]

16. Chaberek-Karwacka, G. Streets as Factors for and Barriers to Cities in Sustaining Development: A Comparison of Gothenburg and Gdansk. In Making Cities Resilient, the Urban Book Series; Sharma, V., Chandrakanta, Eds.; Springer Nature Switzerland AG: Cham, Switzerland, 2019. [CrossRef]

17. Rada, E.C. The sustainable city and air pollution. WIT transactions on ecology and the environment. In The Sustainable City IX Vol 191; WIT Press: Southampton, UK, 2014; Volume 2, pp. 1369-1380. ISSN 1743-3541.

18. Vardoulakis, S.; Fisher, B.E.A.; Pericleous, K.; Gonzalez-Flesca, N. Modelling air quality in street canyons: A review. Atmos Environ. 2003, 37, 155-182. [CrossRef]

19. Oke, T.R. Boundary Layer Climates, 2nd ed.; Methuen: London, UK, 1978.

20. Sini, J.F.; Anquetin, S.; Mestayer, P.G. Pollutant dispersion and thermal effects in urban street canyons. Atmos. Environ. 1996, 30, 2659. [CrossRef]

21. Salizzoni, P.; Soulhac, L.; Mejean, P. Street canyon ventilation and atmospheric turbulence. Atmos Environ. 2009, 43, 5056-5067. [CrossRef]

22. Murena, F. Monitoring and modelling carbon monoxide concentrations in a deep street canyon: Application of a two-box model. Atmos. Pollut. Res. 2012, 3, 311.

23. Tang, J.; McNabola, A.; Misstear, B. The potential impacts of different traffic management strategies on air pollution and public health for a more sustainable city: A modelling case study from Dublin, Ireland. Sustain. Cities Soc. 2020, 60, 102229. [CrossRef]

24. Shafique, M.; Xue, X.; Luo, X. An overview of carbon sequestration of green roofs in urban areas. Urban For. Urban Green. 2020, 47, 126515.

25. Potienko, N.; Kuznetsova, A.; Soya, D. Green Energy Technologies of Tall Buildings for Air Pollution Abatement in Metropolises. In EMMFT 2018; Murgul, V., Pasetti, M., Eds.; Springer Nature Switzerland AG: Cham, Switzerland, 2020; Volume 982, pp. 105-115.

26. Murena, F. Solar towers for a better air quality in urban areas: Analysis of performances. In Proceedings of the 1st International Conference on Applications of Air Quality in Science and Engineering Purposes, Shuwaikh, Kuwait, 10-12 February 2020.

27. Sohrabi, S.; Zietsman, J.; Khreis, H. Burden of Disease Assessment of Ambient Air Pollution and Premature Mortality in Urban Areas: The Role of Socioeconomic Status and Transportation. Int. J. Environ. Res. Public Health 2020, 17, 1166. [CrossRef]

28. Samol, E.; Stergiopoulou, A.; Santana, P.; Rodopoulou, S.; Mitsakou, C.; Dimitroulopoulou, C.; Bauwelinck, M.; de Hoogh, K.; Costa, C.; Marí-Dell'Olmo, M.; et al. Spatial variability in air pollution exposure in relation to socioeconomic indicators in nine European metropolitan areas: A study on environmental inequality. Environ. Pollut. 2019, 249, 345-353. [CrossRef] [PubMed]

29. Murena, F.; Vorraro, F. Vertical gradients of Benzene in a narrow street canyon in urban area of Naples. Atmos. Environ. 2003, 37, 4853-4859. [CrossRef]

30. Murena, F.; Favale, G. Continuous monitoring of carbon monoxide in a deep street canyon. Atmos. Environ. 2007, 41, 2620-2629. [CrossRef]

31. Kumar, P.; Robins, A.; Vardoulakis, S.; Britter, R. A review of the characteristics of nanoparticles in the urban atmosphere and the prospects for developing regulatory controls. Atmos. Environ. 2010, 44, 5035-5052. [CrossRef]

32. Terracciano, C. Fine particles concentration in a street canyon. In Master Thesis in Environmental Engineering; University of Naples "Federico II": Naples, Italy, 2019.

33. Kumar, P.; Morawska, L.; Birmili, W.; Paasonen, P.; Hu, M.; Kulmal, M.; Harrison, R.M.; Norford, L.; Britter, R. Ultrafine particles in cities. Environ. Int. 2014, 66, 1-10. [CrossRef] [PubMed]

34. Murena, F.; Prati, M.V. Spatial variability of fine particle number concentration in an urban area. In Proceedings of the Seventh International Conference on Environmental Management, Engineering, Planning and Economics (CEMEPE 2019) and SECOTOX Conference, Mykonos Island, Greece, 19-24 May 2019. 
35. Buonanno, G.; Fuoco, F.C.; Stabile, L. Influential parameters on particle exposure of pedestrians in urban microenvironments. Atmos. Environ. 2011, 45, 1434-1443. [CrossRef]

36. Mej1a, J.F.; Morawsk, L.; Mengersen, K. Spatial variation in particle number size distributions in a large metropolitan area. Atmos. Chem. Phys. 2008, 8, 1127-1138.

37. Birmili, W.; Tomsche, L.; Sonntag, A.; Opelt, C.; Weinhold, K.; Nordmann, S.; Schmidt, W. Variability of aerosol particles in the urban atmosphere of Dresden (Germany): Effects of spatial scale and particle size. Meteorol. Z. 2013, 22, 195-211. [CrossRef]

38. Murena, F.; Prati, M.V. The contribution of high emitters vehicles to FPs number concentration in the historical center of Naples. In Proceedings of the 12th International Conference on Air Quality-Science and Application, Thessaloniki, Greece, 9-13 March 2020.

39. Chianese, E.; Tirimberio, G.; Riccio, A. $\mathrm{PM}_{2.5}$ and $\mathrm{PM}_{10}$ in the urban area of Naples: Chemical composition, chemical properties and influence of air masses origin. J. Atmos. Chem. 2019, 76, 151-169. [CrossRef]

40. Panagiotou, M.K.A.; Neophytou, D.; Hamlyn, R.E.; Britter, R. City breathability as quantified by the exchange velocity and its spatial variation in real inhomogeneous urban geometries: An example from central London urban area. Sci. Total Environ. 2013, 442, 466-477. [CrossRef]

41. Toscano, D.; Murena, F. The effect on air quality of lock down directives to prevent the spread of SARS-CoV-2 pandemic in Campania region-Italy. Indications for a sustainable development. Sustainability 2020, 12, 5558. [CrossRef]

42. Murena, F.; Mocerino, L.; Quaranta, F.; Toscano, D. Impact on air quality of cruise ship emissions in Naples, Italy. Atmos. Environ. 2018, 187, 70-83. [CrossRef]

(C) 2020 by the author. Licensee MDPI, Basel, Switzerland. This article is an open access article distributed under the terms and conditions of the Creative Commons Attribution (CC BY) license (http://creativecommons.org/licenses/by/4.0/). 